\title{
Menisporopsin B, a New Polyester from the Seed Fungus Menisporopsis theobromae BCC 4162
}

\author{
Vasimon Ruanglek, Supichar Chokpaiboon, Nakul Rattanaphan, Siribhorn Madla, \\ Patchanee Auncharoen, Taridaporn Bunyapaiboonsri, Masahiko Isaka
}

Received: September 17, 2007 / Accepted: December 10, 2007

(C) Japan Antibiotics Research Association

\begin{abstract}
A new linear polyester, menisporopsin B, along with the known macrocyclic polyester, menisporopsin A, was isolated from the seed fungus Menisporopsis theobromae BCC 4162. The structure of menisposopsin B was addressed primarily by spectroscopic analyses, and the stereochemistry was established by chemical correlation. Menisporopsin B exhibited antimalarial activity with an $\mathrm{IC}_{50}$ value of $1.0 \mu \mathrm{g} / \mathrm{ml}$.
\end{abstract}

Keywords Menisporopsis theobromae, seed fungi, menisporopsin B, polyester

As part of the research program on novel bioactive compounds from local fungi in Thailand [1, 2], we previously reported the isolation of an antimalarial and cytotoxic macrocyclic polyester, menisporopsin A (1), from the seed fungus Menisporopsis theobromae BCC 4162, which was fermented in peptone-yeast extract - glucose medium (PYGM) under static condition [3]. Recent studies on optimization of culture conditions led to the conclusion that fructose, instead of glucose in PYGM, is more suitable as carbon source [4]. Shaking not only enhanced the production of menisporopsin $\mathrm{A}$, but also reduced the incubation time [4]. Taken these two factors together, fermentation of BCC 4162 in peptone-yeast extract-

T. Bunyapaiboonsri (Corresponding author), V. Ruanglek, S. Chokpaiboon, N. Rattanaphan, S. Madla, P. Auncharoen, M. Isaka: National Center for Genetic Engineering and Biotechnology (BIOTEC), Thailand Science Park, 113 Phaholyothin Road, Klong 1, Klong Luang, Pathumthani 12120, Thailand,

E-mail: taridaporn@biotec.or.th. fructose medium (see Experimental) under shaking condition was further studied. In addition to menisporopsin A, a new metabolite was discovered in the time profile studies. Therefore, we have undertaken the large scale fermentation, isolation and structure elucidation of the new analogue, menisporopsin B (2).

\section{Results and Discussion}

2 was isolated as a white solid with the same molecular formula as $1\left(\mathrm{C}_{40} \mathrm{H}_{46} \mathrm{O}_{17} ; m / z 821.2626\right.$ for $[\mathrm{M}+\mathrm{Na}]^{+}$, $\Delta=-0.7 \mathrm{mmu}) .2 \mathrm{D}$ NMR data $\left({ }^{1} \mathrm{H}-\mathrm{NMR},{ }^{13} \mathrm{C}-\mathrm{NMR}, \mathrm{COSY}\right.$, NOESY, HMQC, and HMBC) suggested that this compound possessed a unit of 3,4-dihydro-6,8-dihydroxy-3-(2hydroxypropyl)isocoumarin, two units of 2,4-dihydroxy-6(2-hydroxypropyl)benzoic acid and two units of 3hydroxybutyric acid. ${ }^{1} \mathrm{H}$ - and ${ }^{13} \mathrm{C}-\mathrm{NMR}$ spectra of $\mathbf{2}$ revealed resonances close to those of $\mathbf{1}$ for both two units of dihydroxybenzoic acid and a unit of 3-hydroxybutyric acid. Notable NMR differences between these two compounds were the downfield resonances of H-9/C-9 $\left(\delta_{\mathrm{H}} 4.77 / \delta_{\mathrm{C}}\right.$ $76.1)$, and upfield shifts of $\mathrm{H}-39 / \mathrm{C}-39\left(\delta_{\mathrm{H}} 4.03 / \delta_{\mathrm{C}} 63.8\right)$ of 2 when compared to those of $1\left(\mathrm{H}-9 / \mathrm{C}-9, \delta_{\mathrm{H}} 3.95 / \delta_{\mathrm{C}} 69.1\right.$; and $\mathrm{H}-39 / \mathrm{C}-39, \delta_{\mathrm{H}} 5.56$ or $5.54 / \delta_{\mathrm{C}} 69.3$ or 69.8$)$. On the basis of these data, an ester linkage at C-9 (instead of a secondary alcohol), and a terminal hydroxyl group at C-39 (instead of an ester linkage) were proposed for 2 . The dihydroisocoumarin unit and the terminal 3-hydroxybutyric acid unit of $\mathbf{2}$ were assigned based on COSY cross signals and $\mathrm{HMBC}$ data. From ${ }^{13} \mathrm{C}$-NMR/DEPT spectra, an ester carbonyl $\left(\delta_{\mathrm{C}} 170.3\right)$, four aromatic quaternary carbons $\left(\delta_{\mathrm{C}}\right.$ $165.1,164.2,141.8$ and 100.4$)$, two aromatic methines $\left(\delta_{\mathrm{C}}\right.$ 107.0 and 101.2), two oxygenated methines $\left(\delta_{\mathrm{C}} 76.1\right.$ and 


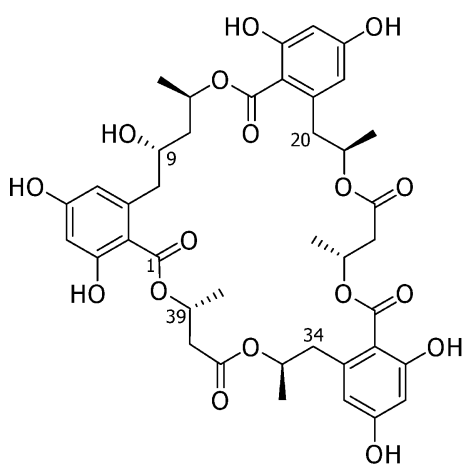

Menisporopsin A (1)

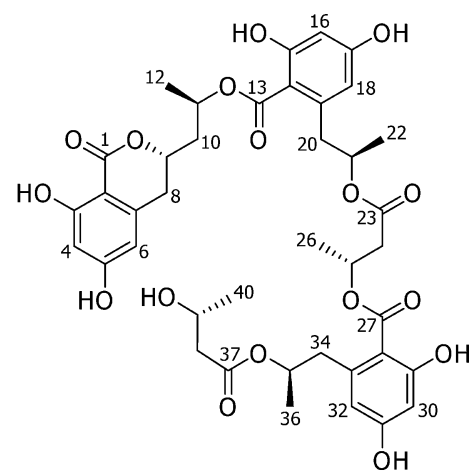

Menisporopsin B (2)

Fig. 1 Structures of menisporopsins A (1) and B (2).

69.3), two methylene carbons ( $\delta_{\mathrm{C}} 40.5$ and 32.7$)$, and a methyl group $\left(\delta_{\mathrm{C}}\right.$ 19.3) were observed for the dihydroisocoumarin unit. COSY cross signals suggested partial structure from $\mathrm{C}-8$ to $\mathrm{C}-12$, while the remaining part from $\mathrm{C}-1$ to $\mathrm{C}-8$ was assigned based on ${ }^{1} \mathrm{H}$ and ${ }^{13} \mathrm{C}$ chemical shift values, and $\mathrm{HMBC}$ correlations from $\mathrm{H}-8$ to C-2, C-6 and C-7, and from H-6 to C-1, C-2, C-4 and C-8. The sequence of all five hydroxy acid units via ester linkages was determined by HMBC correlations observed from H-11 to C-13, H-21 to C-23, H-25 to C-27, and H 35 to $\mathrm{C}-37$, therefore, the gross structure of $\mathbf{2}$ was established.

By structural comparison, it was assumed that $\mathbf{2}$ derived from 1 via intramolecular translactonization. The time profile of metabolite production strongly suggested that this transformation occurred during fermentation period. To correlate the stereochemistry, chemical transformation of $\mathbf{1}$ to $\mathbf{2}$ was examined. Treatment of $\mathbf{1}$ with $\mathrm{K}_{2} \mathrm{CO}_{3}$ in THF at room temperature for 16 hours gave $\mathbf{2}$ as a sole product. Accordingly, the absolute configuration of $\mathbf{2}$ was shown to be the same as $\mathbf{1}$.

The antimalarial and cytotoxic activities of $\mathbf{2}$ were close to those of $\mathbf{1} . \mathbf{2}$ exhibited antimalarial activity against Plasmodium falciparum $\mathrm{K} 1$ with an $\mathrm{IC}_{50}$ value of $1.0 \mu \mathrm{g} / \mathrm{ml}$. It also displayed cytotoxic activities against cancer cell-lines, BC, KB, and NCI-H187 (with respective $\mathrm{IC}_{50}$ values of $3.7,8.9$, and $4.8 \mu \mathrm{g} / \mathrm{ml}$ ), and non-malignant Vero cells with an $\mathrm{IC}_{50}$ value of $16.4 \mu \mathrm{g} / \mathrm{ml}$.

Macrocyclic or linear polyesters consisting of 2,4dihydroxy-6-(2-hydroxypropyl)benzoic acid and 3hydroxybutyric acid residues have been reported as metabolites of Hypoxylon oceanicum [5], Penicillium verruculosum [6, 7], and Scedosporium apiospermum [8], whereas macrocyclic or linear polyesters containing 3,4dihydro-6,8-dihydroxy-3-(2-hydroxypropyl)isocoumarin residues are unusual.

\section{Experimental}

\section{Extraction and Isolation}

The fungus BCC 4162 was incubated in $800 \mathrm{ml}$ of peptone-yeast extract-fructose medium (fructose $10 \mathrm{~g}$, yeast extract $20 \mathrm{~g}$, bacto-peptone $5.0 \mathrm{~g}$, ammonium tartrate $0.5 \mathrm{~g}, \mathrm{KH}_{2} \mathrm{PO}_{4} 1.0 \mathrm{~g}, \mathrm{Na}_{2} \mathrm{HPO}_{4} 2.25 \mathrm{~g}, \mathrm{Na}_{2} \mathrm{SO}_{4} 0.28 \mathrm{~g}$, $\mathrm{CaCl}_{2} 0.1 \mathrm{~g}, \mathrm{MgCl}_{2} 0.41 \mathrm{~g}, \mathrm{MnSO}_{4} \cdot 4 \mathrm{H}_{2} \mathrm{O} \quad 44.3 \mathrm{mg}$, $\mathrm{ZnSO}_{4} \cdot 7 \mathrm{H}_{2} \mathrm{O} 40.5 \mathrm{mg}$, ferric citrate $53.1 \mathrm{mg}$ and citric acid $53.1 \mathrm{mg}$, per liter) on a rotary shaker at $200 \mathrm{rpm}$ for 7 days at $25^{\circ} \mathrm{C}$, and then filtered. Mycelia were macerated in $\mathrm{MeOH}(500 \mathrm{ml}, 2$ days) and filtered. The filtrate was diluted with $\mathrm{H}_{2} \mathrm{O}(50 \mathrm{ml})$ and defatted with hexane $(2 \times 300 \mathrm{ml})$. The aqueous $\mathrm{MeOH}$ layer was concentrated under reduced pressure. The residue was dissolved in EtOAc $(350 \mathrm{ml})$, and washed with $\mathrm{H}_{2} \mathrm{O}(100 \mathrm{ml})$. The organic layer was concentrated under reduced pressure to provide a yellow gum $(672.9 \mathrm{mg})$. The crude mycelial extract was fractionated using a Sephadex LH-20 column (elution with $\mathrm{MeOH}$ ) to provide 8 fractions. Fraction 6 was purified by preparative HPLC using a reversed-phase column (Nova-Pak HR $\mathrm{C}_{18}, 6 \mu \mathrm{m}, 25 \times 100 \mathrm{~mm}$; $\mathrm{MeCN}$ : $\left.\mathrm{H}_{2} \mathrm{O}=45: 55\right)$ to furnish $2(43.1 \mathrm{mg})$. Fraction 7 was rechromatographed on a Sephadex LH-20 column (elution with $\mathrm{MeOH})$ to afford $\mathbf{1}(87.9 \mathrm{mg})$.

\section{Menisporopsin B (2)}

White solid; $\mathrm{mp} 119 \sim 120^{\circ} \mathrm{C} ;[\alpha]_{\mathrm{D}}^{26}-79.8($ c 0.2, $\mathrm{MeOH})$; UV $\lambda_{\max }^{\mathrm{MeOH}} \mathrm{nm}(\log \varepsilon) 216$ (5.04), 266 (4.77), 303 (4.45); IR $v_{\max }(\mathrm{KBr}) \mathrm{cm}^{-1} 3388,2982,2935,1714,1649,1620$, 1453, 1315, 1260, 1167, 1094, 1049; HR-MS (ESI-TOF): $m / z \quad 821.2626 \quad[\mathrm{M}+\mathrm{Na}]^{+}$(calcd for $\mathrm{C}_{40} \mathrm{H}_{46} \mathrm{O}_{17} \mathrm{Na}$, 821.2633); ${ }^{1} \mathrm{H}(500 \mathrm{MHz})-$ and ${ }^{13} \mathrm{C}(125 \mathrm{MHz})-\mathrm{NMR}$ data, see Table 1. 
Table 1 NMR data for menisporopsin B in acetone- $d_{6}$

\begin{tabular}{|c|c|c|}
\hline Position & $\delta_{\mathrm{C}}$ & 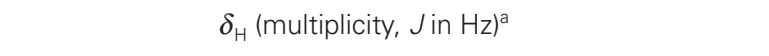 \\
\hline \multicolumn{3}{|c|}{ 3,4-Dihydro-6,8-dihydroxy-3-(2-hydroxypropyl)isocoumarin [1 unit] } \\
\hline 1 & 170.3 & \\
\hline 2 & 100.4 & \\
\hline 3 & $165.1^{b}$ & \\
\hline 4 & 101.2 & $6.23(1 \mathrm{H}, \mathrm{d}, 2.2)$ \\
\hline 5 & $164.2^{b}$ & \\
\hline 6 & 107.0 & $6.29(1 \mathrm{H}, \mathrm{d}, 2.4)$ \\
\hline 7 & 141.8 & \\
\hline 8 & 32.7 & $3.00(1 \mathrm{H}, \mathrm{dd}, 16.4,3.7), 2.93(1 \mathrm{H}, \mathrm{dd}, 16.4,11.0)$ \\
\hline 9 & 76.1 & $4.77(1 \mathrm{H}, \mathrm{d}, \mathrm{m})$ \\
\hline 10 & 40.5 & $2.40(1 \mathrm{H}, \mathrm{ddd}, 14.3,8.1,6.9), 2.11(1 \mathrm{H}, \mathrm{ddd}, 14.3,6.4,5.0)$ \\
\hline 11 & 69.3 & $5.55(1 \mathrm{H}, \mathrm{m})$ \\
\hline 12 & 19.3 & $1.47(3 \mathrm{H}, \mathrm{d}, 6.3)$ \\
\hline \multicolumn{3}{|c|}{ 2,4-Dihydroxy-6-(2-hydroxypropyl)benzoic acid [2 units] } \\
\hline 13,27 & $170.6 ; 169.2$ & \\
\hline 14,28 & $104.7 ; 104.2$ & \\
\hline 15,29 & $165.3^{\mathrm{b}} ; 165.2^{\mathrm{b}}$ & \\
\hline 16,30 & $101.7 ; 101.7$ & $6.26(1 \mathrm{H}, \mathrm{d}, 2.4) ; 6.24(1 \mathrm{H}, \mathrm{d}, 2.4)$ \\
\hline 17,31 & $162.3^{\mathrm{b}} ; 162.5^{\mathrm{b}}$ & \\
\hline 18,32 & $112.7 ; 112.9$ & $6.33(1 \mathrm{H}, \mathrm{d}, 2.5) ; 6.29(1 \mathrm{H}, \mathrm{d}, 2.4)$ \\
\hline 19,33 & $142.6 ; 142.9$ & \\
\hline 20,34 & $42.2 ; 42.3$ & $\begin{array}{l}3.25(1 \mathrm{H}, \mathrm{dd}, 13.3,6.6), 3.05(1 \mathrm{H}, \mathrm{dd}, 13.3,8.8) ; 3.24(1 \mathrm{H}, \mathrm{dd} \text {, } \\
\quad 13.3,5.6), 2.82(1 \mathrm{H}, \mathrm{dd}, 13.5,9.2)\end{array}$ \\
\hline 21,35 & $71.5 ; 70.8$ & $5.23(1 \mathrm{H}, \mathrm{m}) ; 5.15(1 \mathrm{H}, \mathrm{m})$ \\
\hline 22,36 & $19.5 ; 19.7$ & $1.21(3 \mathrm{H}, \mathrm{d}, 6.2) ; 1.23(3 \mathrm{H}, \mathrm{d}, 6.2)$ \\
\hline \multicolumn{3}{|c|}{ 3-Hydroxybutyric acid [1 unit; the middle] } \\
\hline 23 & 169.1 & \\
\hline 24 & 40.4 & $2.73(1 \mathrm{H}, \mathrm{dd}, 15.8,7.3), 2.67(1 \mathrm{H}, \mathrm{dd}, 15.8,5.9)$ \\
\hline 25 & 68.8 & $5.54(1 \mathrm{H}, \mathrm{m})$ \\
\hline 26 & 19.0 & $1.36(3 \mathrm{H}, \mathrm{d}, 6.4)$ \\
\hline \multicolumn{3}{|c|}{ 3-Hydroxybutyric acid [1 unit; the end] } \\
\hline 37 & 170.7 & \\
\hline 38 & 44.0 & $2.32(1 \mathrm{H}, \mathrm{dd}, 14.9,7.0), 2.25(1 \mathrm{H}, \mathrm{dd}, 14.9,6.0)$ \\
\hline 39 & 63.8 & $4.03(1 \mathrm{H}, \mathrm{m})$ \\
\hline 40 & 22.3 & $1.04(3 \mathrm{H}, \mathrm{d}, 6.2)$ \\
\hline
\end{tabular}

${ }^{a}$ Broad signals of phenolic protons were observed at $\delta_{\mathrm{H}} 11.61$ and 11.19. ${ }^{\mathrm{b}}$ Assignment of carbon resonances can be interchanged.

\section{Chemical Transformation of 1 to 2}

To a solution of $\mathbf{1}(3.0 \mathrm{mg})$ in THF $(2.5 \mathrm{ml})$ was added $\mathrm{K}_{2} \mathrm{CO}_{3}(10.0 \mathrm{mg})$. The mixture was stirred at room temperature for 16 hours, and then evaporated under reduced pressure. The residue was dissolved in EtOAc $(8.0 \mathrm{ml})$ and washed with $\mathrm{H}_{2} \mathrm{O}(4 \times 3.0 \mathrm{ml})$. The organic layer was concentrated in vacuo to afford a crude reaction mixture, which was subsequently purified by preparative HPLC $\left(\mathrm{MeCN}: \mathrm{H}_{2} \mathrm{O}=45: 55\right)$ to yield a white solid $(2.5 \mathrm{mg})$. Its specific rotation value, ${ }^{1} \mathrm{H}-\mathrm{NMR}$ and $\mathrm{MS}$ data were identical with those of the isolated 2. The identification was also confirmed using HPLC analysis by co-injection with the isolated $\mathbf{2}$.

Acknowledgment Financial support from the Bioresources Research Network, National Center for Genetic Engineering and Biotechnology (BIOTEC), is gratefully acknowledged. 


\section{References}

1. Isaka M, Kittakoop $\mathrm{P}$, Kirtikara K, Hywel-Jones NL, Thebtaranonth Y. Bioactive substances from insect pathogenic fungi. Acc Chem Res 38: 813-823 (2005)

2. Bunyapaiboonsri T, Yoiprommarat S, Intereya K, Kocharin $\mathrm{K}$. New diphenyl ethers from the insect pathogenic fungus Cordyceps sp. BCC 1861. Chem Pharm Bull 55: 304-307 (2007)

3. Chinworrungsee $M$, Kittakoop $P$, Isaka M, Maithip P, Supothina S, Thebtaranonth Y. Isolation and structure elucidation of a novel antimalarial macrocyclic polylactone, menisporopsin A, from the fungus Menisporopsis theobromae. J Nat Prod 67: 689-692 (2004)

4. Madla S, Kittakoop P, Wongsa P. Optimization of culture conditions for production of antimalarial menisporopsin A by the seed fungus Menisporopsis theobromae BCC 4162 . Lett Appl Microbiol 43: 548-553 (2006)

5. Schlingmann G, Milne L, Carter GT. Isolation and identification of antifungal polyesters from the marine fungus Hypoxylon oceanicum LL-15G256. Tetrahedron 58: 6825-6835 (2002)

6. Ito M, Tsuchida Y, Mizoue K, Hanada K. NG-011 and NG012, novel potentiators of nerve growth factor. II. The structure determination of NG-011 and NG-012. J Antibiot 45: 1566-1572 (1992)

7. Breinholt J, Jensen GW, Nielsen RI, Olsen CE, Frisvad JC. Antifungal macrocyclic polylactones from Penicillium verruculosum. J Antibiot 46: 1101-1108 (1993)

8. Kondo H, Kurama M, Nakajima S, Osada K, Ookura A, Suda H. Estrogenic BE-26263 and its manufacture with Scedosporium apiospermum. Jpn Kokai Tokkyo Koho: JP 05032658 (1993) 